\title{
Makam Gus Dur, Ikon Pariwisata Jombang*
}

\author{
Lexi Pranata \& Dewa Gde Satrya*** \\ *Salah Satu Luaran Penelitian Dosen Pemula, Kemenristekdikti, 2017 \\ ** Dosen Bisnis Hospitaliti, Universitas Ciputra
}

\begin{abstract}
Tebuireng Islamic Boarding School, Jombang district, which is integrated with the tombs of the founders of the Nahdlatul Ulama (NU) and national heroes, is increasingly visited by pilgrims since KH. Abdurrahman Wahid (Gus Dur) died and was buried there. The arrival of the pilgrims was in addition to a form of homage to the scholars of the founders of Nadhlatul Ulama (NU), also to pray. This motivation is typical in pilgrimage tours. Gus Dur's grave deserves to be designated as an icon of Jombang district tourism. As a pilgrimage tourist destination, the iconic tomb complex with Gus Dur's Tomb has several advantages to be designated as Jombang tourism icons which are then expected to provide added value for Jombang district. This article is conceptual paper, giving a review of Gus Dur's grave designation as an icon of Jombang tourism. The research approach is qualitatively descriptive, where primary data sources are obtained from data collection through interviews and supported by the observation process. Secondary data sources are carried out through the study of related literature. The formulation of the problem in this study is how the chances of Gus Dur's grave becoming an icon of Jombang tourism? The conclusion of this study is that the tomb of Gus Dur is appropriate to be used as an icon of Jombang tourism, with consideration, first, the tomb of Gus Dur have an advantage as a heritage area that has high historical value, and is strategically significant for the progress of Jombang tourism in particular. Second, the geographical location of Gus Dur's tomb which became one area with Tebuireng Islamic Boarding School, also higher education, and the National Islamic Museum K.H. Hasyim Asy'ari in one area will focus the relevant government agencies to carry out development programs as a follow-up to iconic tourism designation. Third, the Tomb of Gus Dur is important area in the establishment of NU, which is expected to have a positive impact on the surrounding area when arranged in such a way. Fourth, in terms of tourism components, Gus Dur's Grave has complete appeal, good accessibility, existing facilities but needs to be developed.
\end{abstract}

Keywords: Gus Dur's tomb, tourist icon

\section{PENDAHULUAN}

Pariwisata menjadi daya tarik bagi semakin banyak daerah di Indonesia. Secara nasional, pertumbuhan kontribusi pendapatan asli daerah (PAD) dari sektor pariwisata, menjadi cerminan tumbuhnya industri pariwisata. Semakin banyak destinasi baru yang muncul di berbagai daerah, menunjukkan bahwa industri pariwisata di daerah semakin banyak diminati dan direspons positif oleh pasar wisatawan.

Persaingan bisnis pariwisata antar-destinasi wisata daerah di Indonesia semakin ketat. Tingkat persaingan yang tinggi tersebut mensyaratkan adanya diferensiasi dan keunggulan bersaing masing-masing daerah untuk meningkatkan daya tarik wisata yang ada dan selanjutnya terjadi pertumbuhan jumlah wisatawan. Kemungkinan bagi Kabupaten Jombang untuk memperkuat ikon pariwisata yang di tahapan berikutnya menjadi 'penanda' dan menjadi sebagian indikator peran pemerintah dalam pembangunan di sektor pariwisata dinilai urgen.

Momentum ini dapat dimaknai sebagai sinyal adanya kebutuhan untuk memperkuat simpul pariwisata Jombang dengan perumusan dan penetapan ikon pariwisata yang menunjang 
dan menjadi pembeda serta di masa selanjutnya akan menjadi salah satu sumber keunggulan bersaing bagi destinasi wisata Jombang. Hal tersebut juga dirumuskan oleh ahli, salah satunya Baker (2007: 92) menyatakan bahwa beberapa variabel yang dapat digunakan dalam penentuan positioning suatu destinasi adalah kombinasi beberapa variabel yang dapat menjadi pembeda serta keunggulan bersaing destinasi wisata dengan destinasi lain sebagai berikut.

- Arsitektur dan design

- Atraksi wisata

- Iklim

- Sejarah dan kebudayaan

- Even

- Industri dan produk lokal

- Landmarks dan ikon

- Legenda dan mitos

- Lokasi dan akses

- Lingkungan dan masyarakat

Ikon dan landmarks menjadi unsur penting dalam pembentukan ciri khas dan positioning pariwisata Jombang. Beberapa literatur menunjukkan adanya kesamaan penggunaan kata 'ikon' dalam ranah pariwisata dengan 'simbol' dan 'representatif'.

Keberhasilan penentuan dan pengomunikasian ikon akan berimplikasi pada pengembangan daya saing pariwisata Jombang. Demikian sebaliknya, penentuan ikon yang tidak tepat dan tidak terkomunikasikan dengan baik, tidak berfaedah dalam memberikan kontribusi untuk menciptakan positioning yang kuat bagi pengembangan destinasi pariwisata di Jombang.

Di jangka panjang, pertumbuhan sektor pariwisata dengan salah satu unsur pentingnya adalah keberhasilan dalam penentuan dan pengomunikasian ikon pariwisata daerah, akan mempercepat tercapainya tujuan kepariwisataan yang diamanatkan Pasal 4 dalam UU 10/2009 tentang
Kepariwisataan, di antaranya menghapus kemiskinan, mengatasi pengangguran, meningkatkan pertumbuhan ekonomi, dan kesejahteraan rakyat.

Ikon pariwisata Jombang merupakan bagian penting dari positioning pariwisata Jombang dalam industri pariwisata global dan menjadi dasar pengembangan kawasan dalam kompetisi untuk menarik pasar wisatawan. Rumusan masalah dalam penelitian ini adalah bagaimana peluang Makam Gus Dur menjadi ikon pariwisata Jombang?

\section{KAJIAN PUSTAKA}

Ikon

Dalam ilmu komunikasi, istilah ikon merupakan bagian dari 'teori dasar tentang tanda' yang dicetuskan oleh Charles Peirce. Teori 'Peircean' mengemukakan bahwa ikon merupakan suatu tanda yang dapat berbentuk replikasi atau persamaan. Danesi (2004: 372), ikon (icon) sebagai tanda di mana penanda memiliki koneksi langsung (non-arbitrer) dan simulatif dengan petanda atau sumber acuannya.

Holt (2004) mengartikan sisi lain dari ikon, tidak seperti pandangan yang dikemukakan dalam ilmu semiotika. Holt berpendapat bahwa ikon muncul dari sebuah brand secara konvensional. Ketika hal tersebut terus-menerus digemari dan disebutkan serta diminati maka brand tersebut menjadi sebuah ikon (Holt, 2004: 231).

Beberapa peneliti telah mengidentifikasi bahwa ikon dapat diterima oleh publik manakala memiliki asosiasi dengan sejarah dan budaya lokal serta adanya keterlibatan pemerintah dalam pariwisata (Jafari, 1987; Kalven, 1988; Katz \& Lee, 1992, dalam Tang et al., 2009).

Berikut ini merupakan model konseptual kriteria efektivitas ikon sebagai atraksi wisata yang dikembangkan oleh Tang et al. (2009) 


\section{Effectiveness Criteria for Icons as Tourist Attractions}

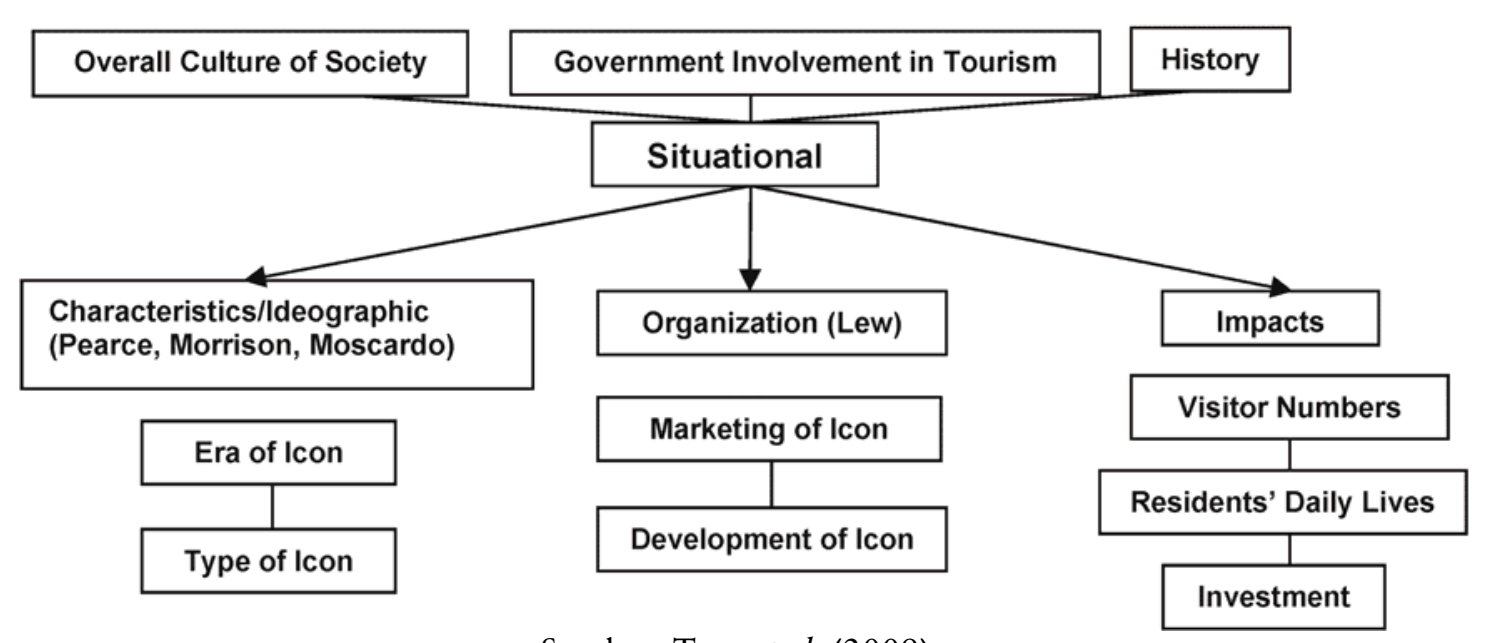

Sumber: Tang et al. (2009)

Gambar 1 Model Konseptual Kriteria Efektivitas Ikon Atraksi Wisata

dalam artikelnya dengan judul Effectiveness Criteria for Icons as Tourist Attractions: A Comparative Study between the United States and China. Tiga faktor situasional yang memengaruhi operasional ikon dalam suatu atraksi wisata, yakni faktor budaya, sejarah, dan keterlibatan pemerintah. Mereka juga menganjurkan ikon atraksi wisata dievaluasi dengan tiga aspek: karakteristik ikon, organisasi, dan dampaknya.

Ikon yang dimaksud merujuk pada beberapa figur orang terkenal. Sebagai contoh beberapa ikon dari orang terkenal dan keterkaitannya dengan atraksi wisata: William J. Clinton dalam Presidential Center and Park di Little Rock, Arkansas, USA, Alexandre Dumas di Fife Island, Marseille, Prancis, dan Mao Zedong di Shaoshan, Hunan, China.

Pearce et al. (2003, dalam Tang et al. 2009) mengklasifikasikan ikon ke dalam tiga era: era historis, modern, dan kontemporer. Ikon historis merujuk pada orang terkenal di abad ke-17 atau sebelumnya. Ikon era modern didefinisikan dari orang yang terkenal pada abad ke-18 dan 19 . Ikon era kontemporer merepresentasikan indi- vidu yang terkenal di abad ke-20 dan 21. Pearce et al. (2003) juga mengidentifikasi lebih lanjut kategori untuk individu yang ditetapkan sebagai ikon atraksi wisata, yakni: ikon politik, dunia hiburan (film, musik), olah raga, pelaku tindak kriminal, eksplorer dan penemu, sastrawan, figur mistik, militer, religius, serta pengusaha.

\section{Pariwisata}

Beberapa ahli mendefinisikan pariwisata sebagai berbagai kegiatan yang ada kaitannya dengan wisatawan (Soekadijo, 2000: 3). A.J. Burkart dan S. Medlik, Tourism, Past, Present and Future (ibid, hal. 3) menyatakan bahwa pariwisata berarti perpindahan orang dalam jangka pendek ke suatu tempat di luar tempat tinggalnya. Gamal Suwantoro (1997) mendefinisikan pariwisata sebagai suatu proses bepergian sementara untuk kegiatan ekonomi, aktivitas sosial budaya, atau sekadar ingin tahu untuk menambah pengalaman.

Terdapat berbagai bentuk wisata yang bisa menampilkan sebuah pesona yang bisa wisata- 
wan. Pariwisata sendiri merupakan suatu area yang sangat luas, sehingga banyak ahli yang membaginya ke dalam beberapa bagian (Swarbrooke dan Horner, 1999: 29-38).

a. VFR (visiting friends and relatives) VFR pada dasarnya adalah keinginan untuk bertemu saudara atau teman.

b. Wisata bisnis (business tourism) Wisata bisnis pada dasarnya adalah sebuah wisata yang ada kaitannya dengan kegiatan yang termasuk dalam MICE (meeting, incentive, convention, exhibition).

c. Wisata ziarah (religious tourism)

Wisata keagamaan termasuk kunjungan-kunjungan ke berbagai tempat yang mengandung unsur religius. Kunjungan-kunjungan ini di kategorikan sebagai sebuah wisata karena di samping mendapatkan nilai-nilai rohani maka peserta juga mendapatkan nuansa baru dari lingkungan sekitarnya.

d. Wisata kesehatan (health tourism)

Wisata kesehatan adalah perjalanan dengan tujuan untuk kesehatan.

e. Wisata sosial (social tourism)

Wisata sosial adalah kegiatan yang melibatkan banyak orang.

f. Wisata pendidikan (educational tourism)

Wisata pendidikan adalah perjalanan dengan tujuan untuk memperoleh pendidikan secara formal.

g. Wisata alam (scenic tourism)

Wisata alam bertujuan untuk menikmati panorama alam.

h. Wisata aktivitas (activity tourism)

Wisata untuk mendapatkan pengalaman baru.

i. Wisata budaya (cultural tourism)

Wisata budaya menampilkan daya tarik dari aktivitas atau rutinitas yang di lakukan oleh sebuah komunitas yang memberikan daya tarik untuk dikunjungi dan dinikmati.

\section{METODOLOGI}

Metode penelitian ini secara kualitatif. Metode kualitatif ditempuh untuk memperoleh pemahaman yang lebih baik mengenai interaksi sosial antarmanusia (Sarwono, 2006: 193). Rancangan penelitian eksplorasi (exploratory) digunakan untuk riset awal yang berfungsi untuk menjelaskan dan mendefinisikan suatu masalah.

Sarwono (2006: 81) menyatakan bahwa riset eksplorasi bersifat awal sehingga tidak dimaksudkan untuk mencari kesimpulan akhir. Oleh karena itu, proses wawancara dan didukung observasi yang dilakukan dalam penelitian ini adalah untuk memotret tema penelitian guna menggali kemungkinan dijadikannya Makam Gus Dur sebagai ikon pariwisata Jombang.

Data sekunder didapat dari literatur yang relevan mengenai ikon pariwisata serta penelitian sebelumnya di objek terkait. Penelitian sebelumnya memberikan panduan bagi peneliti dalam melakukan observasi.

\section{PEMBAHASAN}

Kabupaten Jombang merupakan area yang strategis di Jawa Timur berbatasan dengan Mojokerto, Kediri, Nganjuk, juga Malang. Dari sisi potensi wisata, Jombang memiliki potensi pariwisata alam dan religi. Sejak Gus Dur wafat dan dimakamkan di kompleks Pondok Pesantren Tebuireng, kompleks pemakaman para ulama dan keluarga pendiri Nahdlatul Ulama semakin ramai didatangi peziarah.

Protokoler Ponpes Tebuireng, Teuku Aswani, menyatakan bahwa "peziarah Makam Gus Dur tidak hanya umat Islam, tetapi umat lintas agama, dan bahkan lintas negara. Ini menunjukkan bahwa Gus Dur menjadi milik bangsa.”

Pernyataan di atas juga diperkuat dengan Nisan penanda Makam Gus Dur yang baru 
terpasang pada tahun 2017. Nisan berbahan granit berusia tua itu tertulis dalam empat bahasa (Indonesia, Arab, Inggris, dan Mandarin), “Di Sini Terbaring Pejuang Kemanusiaan, K.H. Abdurrahman Wahid.” Maknanya, semasa hidupnya Gus Dur tidak hanya menjadi teladan dalam menjalankan kesalehan beragama, tetapi menjunjung tinggi nilai kemanusiaan yang universal.

Jumlah peziarah pada hari biasa mencapai ribuan dan lebih meningkat pada hari-hari libur. Jumlah wisatawan kawasan wisata religi Makam Gus Dur Kabupaten Jombang 2011-2013: perkembangan jumlah wisatawan mengalami peningkatan rata-rata 15\% tiap tahunnya 771,104 (tahun 2011), 885,649 (tahun 2012), 1,088,070 (tahun 2013), dan bahkan banyaknya jumlah wisatawan dan kawasan ini tahun 2013 (1.088.070) di atas jumlah wisatawan Sunan Derajat Lamongan (465.267) dan kawasan religi MM Ibrahim Gresik (870.237). Hanya kelemahannya adalah penyebaran jumlah wisatawan $71.6 \%$ terfokus pada kawasan wisata religi Gus Dur dari 13 kawasan wisata lain di Kabupaten Jombang (Bappeda Jombang, 2015).

Karena itu, kedatangan para peziarah ini sepantasnya disambut dengan baik, yang dalam kaitan ini terpenuhinya Sapta Pesona Wisata: aman, tertib, bersih, sejuk, indah, ramah, memberi kenangan yang positif, dan mendalam. Oleh karena itu, infrastruktur dan faktor manusia memegang peran penting dalam implementasi Sapta Pesona Wisata yang akan berkontribusi pada kepuasan berziarah di kalangan peziarah.

Observasi di area Makam Gus Dur menemukan beberapa informasi perihal Sapta Pesona Wisata tersebut. Pertama, dari sisi keamanan dirasakan baik, namun hal ini harus terus terpelihara. Mengingat pengunjung Makam Gus Dur tidak hanya kalangan peziarah biasa, tetapi banyak sekali tokoh nasional dan mancanegara yang datang ke Makam Gus Dur. Kedua, ketertiban di area Makam Gus Dur telah terpelihara. Pengaturan parkir kendaraan umum, khususnya bus pariwisata, dan kendaraan pribadi tertata baik.

Ketiga, kebersihan area Makam Gus Dur merupakan tantangan tersendiri. Hal ini membutuhkan kesadaran dari para wisatawan/peziarah untuk terus menerus memelihara kebersihan di area Makam Gus Dur. Telah terlihat tempat sampah yang disediakan pengelola di titik-titik yang dilalui peziarah. Studi Bappeda Jombang (2015) mengusulkan peningkatan kualitas pengelolaan sampah.

Kelima, kesejukan dan keindahan, menjadi satu paduan yang saling terkait. Penataan pepohonan di sekitar area parkir menambah keindahan. Ketertiban penataan area pedagang juga menambah keindahan area Makam Gus Dur.

Terakhir, kenangan yang mendalam merupakan tantangan bagi segenap pengelola objek wisata untuk terus menerus mengupayakan kesan yang positif dan menyenangkan bagi wisatawan. Demikian halnya Makam Gus Dur, kedatangan peziarah disambut dengan hangat untuk menjaga kekhusukan dan kenyamanan berziarah. Dalam konteks ini, UPT Makam Gus Dur bersama masyarakat lokal berperan penting dan strategis untuk mengelola dan menjaga standard layanan pengunjung Makam Gus Dur yang terintegrasi dengan Museum Islam Nasional K.H. Hasyim Asy'ari. Karena itu, segenap stakeholder terkait di tingkat kabupaten, provinsi, dan nasional perlu bersinergi untuk memastikan kenyamanan berziarah di Makam Gus Dur yang selanjutnya akan meninggalkan kesan yang baik di kalangan wisatawan.

Artikel ini mengusulkan Makam Gus Dur menjadi ikon pariwisata Jombang. Untuk kesesuaian pengembangan destinasi, hanya ikon yang 
relevan yang layak untuk ditentukan atau dipilih. Khususnya, yang bisa memenuhi harapan atau mengundang daya tarik wisatawan, masyarakat lokal dan juga pengelola destinasi wisata tersebut. Ikon wisata yang tepat adalah yang bisa meningkatkan kunjungan wisatawan, berdampak pada keseharian hidup warga lokal, dan bahkan mampu meningkatkan skala investasi pengelola destinasi wisata tersebut.

Gunn (1995) dalam jurnalnya yang berjudul Cultural Tourism Planning mengemukakan lima komponen pariwisata yang harus dikembangkan oleh pihak penyedia layanan wisata, dalam hal ini pengelola Makam Gus Dur, di mana kelima komponen tersebut terintegrasi dalam sebuah sistem pariwisata yang saling bergantung dan saling memengaruhi, yakni (a) daya tarik wisata; (b) pelayanan; (c) promosi; (d) transportasi; dan (e) informasi. Konsep yang dikembangkan Gunn di atas perlu ditindaklanjuti oleh stakeholder terkait pariwisata Jombang untuk menjadikan Makam Gus Dur menjadi ikon pariwisata. Implementasi konsep Gunn membantu memfokuskan pengusulan menjadikan Makam Gus Dur sebagai ikon pariwisata Jombang.

\section{KESIMPULAN DAN SARAN}

\section{Kesimpulan}

Kesimpulan penelitian ini adalah Makam Gus Dur tepat untuk dijadikan ikon pariwisata Jombang, dengan pertimbangan berikut ini.

1. Memiliki keunggulan sebagai kawasan heritage yang memiliki nilai sejarah yang tinggi serta bermakna strategis bagi kemajuan pariwisata Jombang khususnya.

2. Letak geografis Makam Gus Dur yang menjadi satu kawasan dengan Ponpes Tebuireng, institusi pendidikan menengah hingga pendidikan tinggi, serta Museum Islam K.H.
Hasyim Asy'ari akan memfokuskan instansi pemerintah terkait untuk melakukan program-program pembangunan sebagai tindak lanjut dari penetapan ikon pariwisata.

3. Makam Gus Dur merupakan area yang vital dan bernilai penting dalam perintisan berdirinya NU, yang diperkirakan akan berdampak positif pada kawasan di sekitarnya manakala ditata sedemikian rupa.

4. Dilihat dari segi komponen pariwisata, Makam Gus Dur memiliki daya tarik (attractions) yang lengkap, aksesibilitas bagus, dan amenitas sudah ada tetapi perlu dikembangkan.

\section{Saran}

Menindaklanjuti kesimpulan yang dirumuskan di atas, beberapa hal yang disarankan untuk dilakukan adalah sebagai berikut.

1. Sebagai paket dari penetapan ikon pariwisata adalah perlu dirumuskannya maskot, dan jika memungkinkan jingle promosi pariwisata Jombang.

2. Perlu penelitian lebih lanjut untuk mendukung penetapan Makam Gus Dur sebagai ikon pariwisata Jombang.

\section{DAFTAR PUSTAKA}

Baker, Bill. 2007. Destination Branding for Small Cities: The Essentials for Successful Place Branding. USA: Creative Leap Books

Danesi Marcel. 2004. Pesan Tanda dan Makna. Yogyakarta: Jalasutra.

Gunn, Clare A. 1995. Cultural Tourism Planning (Jurnal, serial online), presented at Los Caminos del Rio an International Conference on the Heritage of the Lower RioGrande McAllen, Texas, January $27^{\text {th }}$. http://agrilifecdn.tamu.edu/rpts/files/2011/ 
08/CAG-0011.pdf, Diakses pada 30 Juli 2017.

Holt, Dougles B. 2004. How Brands Become Icons: The Principle of Cultural Branding. Boston: Harvard Business School Press.

Horner, Susana \& Swarbrooke, John. 2005. Leisure Marketing: A Global Perspective. Jordan Hill, Oxford: Elsevier, Butterworth-Heinemann Linacre House.

Kajian Strategi Pengembangan Objek Wisata Religi di Kawasan Makam Presiden RI ke-4 KH. Abdurrahman Wahid. 2015. Badan Perencana Pembangunan Daerah, Pemerintah Kabupaten Jombang

Pitana, I Gede dan Gayatri, Putu G. 2009. Sosiologi Pariwisata. Yogyakarta: Andi.
Sarwono, Jonathan. 2006. Metode Penelitian Kuantitatif dan Kualitatif. Yogyakarta: Graha Ilmu.

Soekadijo, R.G. 2000. Anatomi Pariwisata: Memahami Pariwisata sebagai "Systemic Linkage”. Cetakan Ketiga. Jakarta: Gramedia Pustaka Utama.

Suwantoro, Gamal. 1997. Dasar-Dasar Pariwisata. Yogyakarta: Penerbit Andi.

Tang, Liang, et al. 2009. Effectiveness Criteria for Icons as Tourist Attractions A Comparative Study Between the United States and China. Journal of Travel \& Travel Marketing, 26: 284-302. 
Business and Finance Journal, Volume 4, No. 1, March 2019 